\title{
Ethical Stochastic Objectives Programming Approach for Portfolio Selection
}

\author{
1. Noushin Bagheri \\ $\mathrm{PhD}$ candidate, University of Dubai, UAE, \\ Corresponding author e-mail: s20141023@ud.ac.ae \\ 2. Fouad Ben Abdelaziz \\ Neoma Business School, France, e-mail: fouad.ben.abdelaziz@neoma-bs.fr \\ 3. Ananth Rao \\ University of Dubai, UAE e-mail: arao@ud.ac.ae
}

\begin{abstract}
The paper develops an ethical stochastic multiple objectives programming approach to address the ethical portfolio selection problem in the stochastic environment under the Shari'ah compliant framework. Two random objectives considered in this paper which are maximizing portfolio return and maximizing social welfare of portfolio. The risk of portfolio is measured by covariance matrix of total return. The ethical stochastic multiple objectives programming approach is based on goal programming approach, a chance constrained approach and Shari'ah compliant framework. The model is applied on 60 stocks including conventional and ethical/Islamic securities in GCC. The results show that, portfolios with higher proportion of ethical/Islamic securities in the portfolio and with higher expected loss the higher is the portfolio performance in terms of Sharpe measure.
\end{abstract}

Keywords: Shari'ah compliant, Ethical investment, Goal programming, Multiple objectives, Stochastic multiple objectives programming, Chance constrained approach, Sharpe index as portfolio performance measure

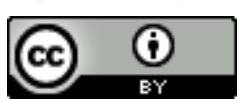

20pyright: (C) 2017 The Authors. This is an open access article distributed under the terms of the Creative Commons Attribution License, which permits unrestricted use, distribution, and reproduction in any medium, provided the original author and source are credited. 


\section{Introduction}

Based on rational behavior the purpose of any business is to maximize profit. Business goals normally has nothing to do with ethics, morality and humanity. However, based on religion, business and morality cannot be separated and business must play fairly and equitably by the rules of morality. This view was emphasized more by the Church in the European countries. The Church prescribed that business must exist only to do good for the society. Repeated financial crisis and especially the recent 2007-2008 financial crisis have raised questions whether such crisis could have been avoided if there were strong ethics embedded in financial transactions, public policy, regulations, governance, and leadership. In addition, erosion of economic value, the social cost to the society and especially to the poor is becoming serious concern for the community. The increased complexity of financial transactions and financial markets, especially with the development of complex derivatives, has also raised ethical issue (Maghrebi et al., 2015).

Additionally, the consideration of ethics and morals of investment decision is becoming more and more important and attractive for some investors who are concerned and care about the right of society and humanity. As a result, ethical investment or social responsible investments (SRI) are growing and academic resources devoted to the study of ethics have also increased in the last two decades. (Maghrebi et al., 2015). Cowton (2004) described ethical investment as: "A set of approaches which include social or ethical goals or constraints in addition to more conventional financial criteria in decisions over whether to acquire, hold or dispose of a particular asset, particularly publicly traded shares, attractive or desirable social characteristics".

Because of the growing interest in ethical investment from society, Islamic finance appears to be a good choice for such investors as ethical investment operate based on Shari'ah compliant framework. The Shari'ah compliance is a religious framework that provides the social and ethical boundaries for business and banking activities (Gassner \& Philipp, 2007). Islamic finance has to comply with Shari'ah compliance which dictates a set of prohibitions such as: "Transactions in unethical goods and services; Earning returns from a loan contract (Riba/Interest); Compensation-based restructuring of debts; Excessive uncertainty in contracts (Gharar); Gambling and chance-based games (Qimar); Trading in debt contracts at discount, and; Forward foreign exchange transactions" (Tariq, 2004).

The consideration of ethics can be seen in all these prohibitions that attract both Islamic and traditional investors globally to ethical investments. Islamic investment are prohibited in specific industries/companies that are believed to be unethical, such as those involved in dealing with alcohol, tobacco, arms defense, pornography, etc., from their investment universe (Ghoul \& Karam, 2007). Table 1. Shows the distinction between Islamic and conventional investments.

2523-6547 - Copyright: (C) 2017 The Authors. This is an open access article distributed under the terms of the Creative Commons Attribution License, which permits unrestricted use, distribution, and reproduction in any medium, provided the original author and source are credited. 
Table 1: comparison between conventional and Islamic investment

\begin{tabular}{|c|c|c|}
\hline Key area & Conventional Investment & Islamic Investment \\
\hline $\begin{array}{l}\text { Main purpose of } \\
\text { investment }\end{array}$ & $\begin{array}{l}\text { The investment seeks to maximize } \\
\text { financial return only. }\end{array}$ & $\begin{array}{l}\text { The investment seeks financial return } \\
\text { while conforming to Shari'ah law. }\end{array}$ \\
\hline $\begin{array}{l}\text { Securities } \\
\text { selection process }\end{array}$ & $\begin{array}{l}\text { Securities selection is made solely based } \\
\text { on the characteristics of the securities } \\
\text { that suit the objectives of the investment } \\
\text { but without reference to any specific } \\
\text { socially-oriented considerations. }\end{array}$ & $\begin{array}{l}\text { Shari'ah guidelines are used as the } \\
\text { screening mechanism in securities } \\
\text { selection process to ensure only halal } \\
\text { approved securities are selected whilst } \\
\text { non-halal securities are avoided. }\end{array}$ \\
\hline Asset universe & $\begin{array}{l}\text { Unlimited. All securities can be selected } \\
\text { or admitted into the conventional } \\
\text { portfolio. }\end{array}$ & $\begin{array}{l}\text { Limited. Only the approved Shari'ah } \\
\text { compliant securities are allowed for } \\
\text { investment. }\end{array}$ \\
\hline $\begin{array}{l}\text { Investment } \\
\text { support services }\end{array}$ & $\begin{array}{l}\text { Only requires investment research } \\
\text { support services to search for } \\
\text { undervalued securities and monitor the } \\
\text { investment performance. }\end{array}$ & $\begin{array}{l}\text { Requires the following services: } \\
\text { 1. Shari'ah advisory board to } \\
\text { screen, monitor and make decision on } \\
\text { securities admissibility or withdrawal. } \\
\text { May also requires Shari'ah officer to } \\
\text { supervise and monitor Shari'ah } \\
\text { compliancy. } \\
\text { 2. Research team to search for } \\
\text { potential securities and monitor funds } \\
\text { performance. }\end{array}$ \\
\hline Type of investors & $\begin{array}{l}\text { Economic rational individuals who } \\
\text { typically prefer more profit and low risk. }\end{array}$ & Religious or ethically-concerned investors \\
\hline
\end{tabular}

Source: (Rahimie, 2010)

\section{Research Problem and Literature Review}

Despite the growing interest in Islamic finance and ethical investment, few empirical studies consider the ethical objective in portfolio selection besides the traditional objectives of risk and return. In this paper we consider, maximizing social welfare as an ethical objective in addition to traditional return and risk objectives for portfolio selection.

In reality there are set of investors who just would like to optimize their investments based on two objectives of maximizing return and minimizing risk. They would derive highest utility if they obtain higher return with minimum level of risk for a particular set of securities in the portfolio. For such investors, the Markowitz (1952) mean-variance framework provides an opportunity to build their portfolio by allocating their wealth through a set of optimal weights in the securities. The mean-variance Markowitz (1952) is as follow:

$$
\begin{aligned}
& \operatorname{Min} \sum_{i=1}^{n} \sum_{j=1}^{n} \sigma_{i j} x_{i} x_{j} \\
& \text { s.t. } \sum_{i=1}^{n} R_{i} x_{i} \geq R^{*} \\
& \sum_{i=1}^{n} x_{i}=1 \\
& 0 \leq x_{i} \leq u_{i}, \quad i=1,2, \ldots, n
\end{aligned}
$$

2523-6547 - Copyright: (C) 2017 The Authors. This is an open access article distributed under the terms of the Creative Commons Attribution License, which permits unrestricted use, distribution, and reproduction in any medium, provided the original author and source are credited. 
where $x_{i}$ is the amount to invest in the $i^{\text {th }}$ security, $R_{i}$ is the random return of the $i^{\text {th }}$ security, $\sigma_{i j}$ is the covariance coefficient between $R_{i}$ and $R_{j}$ and $R^{*}$ is the desired return of the efficient portfolio that investors would like to achieve and $u_{i}$ is the upper limit on investment in the $i^{\text {th }}$ security. The Markowitz (1952) mean-variance model has the capability of considering only two objectives risk and return in the model.

On the other hand, in practice, there are a set of financial decision makers (FDM) who would like to optimize their investments with additional objectives beyond return and risk, and sometimes the objectives are conflicting each other. Zopounidis et al. (1999) provided a list of 15 objectives in portfolio selection that might be considered by FDM such as gross book value per share, capitalization ratio, stock market value of each firm, the marketability of each share, financial position progress, capital gain, transaction value per day, and equity ratio. Another set of objectives proposed by Steuer et al. (2005) include return, dividends, amount invested in R\&D, social responsibility, liquidity, number of securities in portfolio.

However considering multiple criteria in the portfolio selection problem is now a reality for investors. In such a case, Markowitz (1952) bi-objective model does not capture the essence of multi-objectives of the FDM in the financial portfolio selection problem. (Aouni, 2009, 2010). Some multi-dimensional approaches have been proposed in literature that are able to handle multiple conflicting objectives. Among them, goal programming approach is a popular approach. In the Goal programming approach (GP) introduced by Charnes and Cooper (1959), investors can consider multiple conflicting objectives for their portfolio selection in order to attain the efficient portfolio.

However, some of the objectives proposed by Zopounidis et al. (1999) and Steuer et al. (2005) are random objectives such as return, dividend, liquidity and social responsibility. In such a case, the stochastic objectives or random parameters need to be subjected to one of stochastic optimization approaches for portfolio selection. Two approaches have been proposed for handling stochastic multiple objectives. They are chance constrained approach and recourse approach (Ben Abdelaziz et al., 2007).

Ben Abdelaziz et al. (2007) employed the chance constrained compromise programming model (CCCP), which combined the compromise programme (CP) model and the chance constrained programming approach (CCP). They considered three objectives return, exchange flow and risk. The authors assumed that the securities return are random and are normally distributed.

Masmoudi and Abdelaziz (2012) proposed the recourse goal programming approach, which is a mix of the goal programming approach and the recourse approach to solve the portfolio problem when stochastic multiple objectives are involved. They assumed that, investors have a minimum acceptable expected rate of return of their portfolio that if they do not achieve the minimum acceptable return then, they have to pay penalty.

Masri (2015) proposed a multiple stochastic goals approach to the agent portfolio selection. The model is a mixture of goal programming, a chance constrained, and recourse approach by considering two target returns on the return objectives. The author proposed a chance constrained approach which is based on Ben Abdelaziz et al. (2007) to the investor's ideal rate of return that agent would like to achieve to improve agent's reputation in the market. The author proposed recourse approach based on Masmoudi and Ben Abdelaziz (2012) to the investor's minimum rate of return objective that agent should reach to avoid any penalties.

2523-6547 - Copyright: (C) 2017 The Authors. This is an open access article distributed under the terms of the Creative Commons Attribution License, which permits unrestricted use, distribution, and reproduction in any medium, provided the original author and source are credited. 
Substantial research papers exists to handle ethical investments but there are very few that have addressed the stochastic multiple objectives in ethical investment and Islamic finance. Ballestero et al. (2012) added one more objective which is ethical objective to the traditional mean-variance framework. The authors considered the traditional financial objective in the theory of classical utility under uncertainty and an ethical objective in the same utility framework. Two types of assets considered in the model included green or ethical assets, and nonethical assets.

Recently, Masri (2017) proposed a framework which is a combination of goal programming, a chance constrained approach and a recourse approach on Shari'ah compliant portfolio selection in an Islamic security market. The model is based on the principles of Shari'ah by avoiding excessive risks and by providing an ethical and socially responsible approach to portfolio selection. The author proposed the model on two return objectives. The first return objective is to maximize the return of portfolio for a given probability of loss and the second return objective is based on minimum acceptable return. As the Muslim investors need to pay $2.5 \%$ of their return as a Zakat then any return below this amount is consider as a loss and recourse cost.

Ben Abdelaziz and Abed (2018) reviewed different approaches to ethical investment and they mentioned that if the investor is willing to consider ethical securities in their portfolio, then they need to add one more constraint to the bi-objective portfolio selection model. They proposed the ethical constraint as follows:

$$
\sum_{i=1}^{n} e_{i} x_{i} \geq \beta
$$

where $e_{i}$ is an ethical performance score of the $i^{\text {th }}$ security; $\beta$ is regarded as investor's choice for a minimum desired ethical level of the portfolio:

$$
0 \leq \beta \leq \max _{1 \leq i \leq n} e_{i}
$$

\section{Conceptual Framework to Address Research Problem}

Our first objective in this paper is to maximizing the return of the portfolio that yields the maximum profitability or reward from investing in the stock based on traditional Markowitz framework. The second objective of this paper is to include the social welfare return of the portfolio based on ethical investment framework suggested by Ballestero et al. (2012) by maximizing the return of ethical/social responsible investment return (to measure the social welfare of portfolio). The first two objectives are stochastic in nature as return is a random variable. Then chance constrained approach is a suitable approach to model the stochastic objectives on the return objective function. Based on chance constrained the random return objective can be written as follow:

$$
\operatorname{Pr}\left(\sum_{i=1}^{n} R_{i} x_{i} \geq R^{T T}\right) \geq(1-\alpha)
$$

$\alpha$ indicates a threshold defined as $\alpha \in[0,1]$ which is the acceptable level of probability of not achieving investor's targeted value or the acceptable level of probability of loss. We then follow Ben Abdelaziz et al. (2007), and assume that the securities return are normally distributed with known mean and variance. In such a case, the above objective can be written as:

$$
E\left(R^{T T}-\sum_{i=1}^{n} R_{i} x_{i}\right)+\emptyset^{-1}(1-\alpha) \sigma\left(R^{T T}-\sum_{i=1}^{n} R_{i} x_{i}\right) \leq 0
$$

2523-6547 - Copyright: (C 2017 The Authors. This is an open access article distributed under the terms of the Creative Commons Attribution License, which permits unrestricted use, distribution, and reproduction in any medium, provided the original author and source are credited. 
Mathematically this objective can be written as:

$$
E\left(\sum_{i=1}^{n} R_{i} x_{i}\right)-\emptyset^{-1}(1-\alpha) \sigma\left(\sum_{i=1}^{n} R_{i} x_{i}\right) \geq R^{T T}
$$

where $E($.$) and \sigma($.$) are mean and standard deviation of securities return respectively and \emptyset^{-1}$ is the inverse distribution function of a standard normal distribution and $R^{T T}$ is the targeted return that investors would like to achieve as a portfolio return.

For our social welfare objective, based on the chance constrained approach the social welfare constraint can be written the same as the stochastic return constraint, and can be written as follows:

$$
E\left(\sum_{i=1}^{k} R_{i} x_{i}\right)-\emptyset^{-1}(1-\alpha) \sigma\left(\sum_{i=1}^{k} R_{i} x_{i}\right) \geq R^{T S}
$$

where $E($.$) and \sigma($.$) are mean and standard deviation of return on ethical/Islamic securities respectively and R^{T S}$ is the targeted value that ethical or Muslim investors would like to achieve.

To deal with the risk objective of our ethical stochastic multiple objectives programming in our portfolio selection, we use the covariance matrix of total return introduced by Markowitz (1952) and is as follows:

$$
x_{i} V_{i} x_{i}^{\prime}
$$

\subsection{An Ethical Stochastic Multiple Objectives Programming Approach}

The linear equivalent program to the ethical stochastic multiple objectives programming can be written as follows:

$\operatorname{Min} \delta_{1}^{-}+\delta_{2}^{-}+\delta_{3}^{+}$

s.t.

$E\left(\sum_{i=1}^{n} R_{i} x_{i}\right)-\emptyset^{-1}(1-\alpha) \sigma\left(\sum_{i=1}^{n} R_{i} x_{i}\right)+\delta_{1}^{-}=R^{T T} \quad i=1, \ldots k, k+1, \ldots, n$

$E\left(\sum_{i=1}^{k} R_{i} x_{i}\right)-\emptyset^{-1}(1-\alpha) \sigma\left(\sum_{i=1}^{k} R_{i} x_{i}\right)+\delta_{2}^{-}=R^{T s} \quad i=1, \ldots, k$

$x_{i} V x_{i}{ }^{\prime}-\delta_{3}^{+}=0 \quad i=1, \ldots, n$

$0 \leq x_{i} \leq u_{i}, \quad i=1, \ldots, n$

$\delta_{1}^{-}, \delta_{2}^{-}$and $\delta_{3}^{+} \geq 0$

where

$i: 1, \ldots, k:$ ethical/Islamic securities

$i: k+1, \ldots,:$ Conventional securities

$x_{i}$ : the proportion of the $i^{\text {th }}$ security in the portfolio

$R^{T S}$ : the targeted return that investors would like to achieve in order to have impact on society by donating some of this amount as a zakat

$R^{T S}=R^{T I}+Z$

$R^{T I}:$ the targeted return from ethical/Islamic securities

2523-6547 - Copyright: (C) 2017 The Authors. This is an open access article distributed under the terms of the Creative Commons Attribution License, which permits unrestricted use, distribution, and reproduction in any medium, provided the original author and source are credited. 
$Z$ : Zakat rate (Muslim tax; $2.5 \%$ of income)

$V$ : covariance matrix of total return on ethical/Islamic and conventional securities

$x_{i}^{\prime}$ : a transposed vector of $x_{i}$

\section{Model Results}

Historical secondary data on ethical/Islamic and commercial securities such as prices, dividend and other financial data are collected from Eikon (Thomson Reuters) and other reliable resources such as financial markets, for both categories of securities. In particular, the study uses a sample of 60 securities, which include 28 ethical/Islamic securities. All 60 securities are traded in different geographical of GCC from 2006 to 2015 . To solve our problem, we used the LINGO Solver 17.0 and 8GB of RAM using Windows 7. Appendix-1 contains the full list of ethical/Islamic and conventional securities used in the model. We specify our research objectives in a stochastic multiple objectives framework as:

$\operatorname{Min} \delta_{1}^{-}+\delta_{2}^{-}+\delta_{3}^{+}$

s.t.

$E\left(\sum_{i=1}^{60} R_{i} x_{i}\right)-\emptyset^{-1}(1-\alpha) \sigma\left(\sum_{i=1}^{60} R_{i} x_{i}\right)+\delta_{1}^{-}=0.03 \quad i=1, \ldots, 60$

$E\left(\sum_{i=1}^{28} R_{i} x_{i}\right)-\emptyset^{-1}(1-\alpha) \sigma\left(\sum_{i=1}^{28} R_{i} x_{i}\right)+\delta_{2}^{-}=0.07+0.025 i=1, \ldots, 28$

$x_{i} V x_{i}{ }^{\prime}-\delta_{3}^{+}=0 \quad i=1, \ldots, 60$

$0 \leq x_{i} \leq 0.05 \quad i=1, \ldots, 60$

$\delta_{1}^{-}, \delta_{2}^{-}$and $\delta_{3}^{+} \geq 0$

Table2: Attainment of objectives

\begin{tabular}{|c|c|c|c|}
\hline Portfolio & Portfolio 1 & Portfolio 2 & Portfolio 3 \\
\hline$\sum_{i=1}^{28} x_{i}$ & $35 \%$ & $23 \%$ & $15 \%$ \\
\hline Probability of loss $(\alpha)$ & $30 \%$ & $20 \%$ & $10 \%$ \\
\hline Total Return (TR) & 0.0247 & 0.01317263 & 0.00900124 \\
\hline Social Welfare Return (SWR) & 0.04223555 & 0.02950256 & 0.01729355 \\
\hline Risk & 0.01479697 & 0.01176202 & 0.01005761 \\
\hline Sharpe measure TR $(($ TR-0.02) $\div$ Risk $)$ & $32.37 \%$ & $-58.04 \%$ & $-109.35 \%$ \\
\hline Sharpe measure SWR ((SWR-0.02) $\div$ Risk) & $150.27 \%$ & $80.79 \%$ & $-26.90 \%$ \\
\hline
\end{tabular}

Based on the result of our model we calculate the Sharpe performance and we consider the risk free rate in $\mathrm{UAE}$ as a part of GCC at $2 \%$.

The results of the model in Table 2 show the impact of two important issues: the effect of different probability of loss [ $\alpha$ ) equals $10 \%, 20 \%$ and 30\%] on portfolio performance and the effect of different proportion of ethical/Islamic securities $(15 \%, 23 \%$ and $35 \%)$ on portfolio performance. In portfolio 1 the acceptable probability of loss is $30 \%$, and the portfolio comprised of $35 \%$ ethical/Islamic securities. The portfolio total return is $2.47 \%$ which higher than $1.32 \%$ and $0.9 \%$ total return in portfolio 2 and 3 respectively. Portfolios 2 and 3 had acceptable

2523-6547 - Copyright: (C) 2017 The Authors. This is an open access article distributed under the terms of the Creative Commons Attribution License, which permits unrestricted use, distribution, and reproduction in any medium, provided the original author and source are credited. 
probability of loss at $20 \%$ and $10 \%$ respectively with composition of $23 \%$ and $15 \%$ ethical/Islamic securities respectively. The social welfare return of portfolio 1 is $4.22 \%$ which is higher than $2.95 \%$ and $1.73 \%$ in portfolio 2 and 3 respectively.

The risk of portfolio 1 is $1.47 \%$ which is higher than $1.18 \%$ and $1 \%$ in portfolio 2 and 3 respectively. In terms of Sharpe portfolio performance measure, portfolio 1 yielded highest performance of $32.37 \%$ way higher than Portfolio 2 and 3. The results imply that that the acceptance of higher level of probability of loss and inclusion of higher proportion of ethical/Islamic securities have a positive effect on portfolio total return and social welfare objective return and such portfolio perform extremely well.

In the next step we build the Islamic portfolio based on Shari'ah compliant framework and examine the effect of Shari'ah regulation on portfolio performance. The amount of acceptable non permissible income in the portfolio is based on Shari'ah stipulations. According to Official Islamic Indices such as the Dow Jones, S\&P and MSCI, a level of only $5 \%$ of impermissible income is acceptable (D\&J, S\&P\& MSCI Websites 2011). However, based on the Shari'ah Advisory Council (SAC) of the Malaysian Securities and Exchange Commission (SEC), the percentage of impermissible income or activities can range between 5\% and 25\% (Cited by Rahimie, 2010). In this paper we consider only the level of $5 \%$ and $25 \%$ of impermissible activities in the portfolio by adding one more constraint as follows to our model:

$$
\sum_{i=}^{28} x_{i} \geq 95 \% \text { and } \sum_{i=1}^{28} x_{i} \geq 75 \%
$$

Table 3: Attainment of objectives of Islamic portfolio based on Shari'ah compliant

\begin{tabular}{|l|c|c|}
\hline Portfolio & Portfolio 4 & Portfolio 5 \\
\hline$\sum_{i=1}^{28} x_{i}$ & $95 \%$ & $75 \%$ \\
\hline Probability of Loss & $30 \%$ & $30 \%$ \\
\hline Total Return (TR) & 0.082803 & 0.054329 \\
\hline Social Welfare Return (SWR) & 0.075692 & 0.066785 \\
\hline Risk & 0.046913 & 0.023693 \\
\hline Sharpe measure TR ((TR-0.02) $\div$ Risk) & $133.87 \%$ & $144.89 \%$ \\
\hline Sharpe measure SWR ((SWR-0.02) $\div$ Risk) & $118.71 \%$ & $197.46 \%$ \\
\hline
\end{tabular}

The result in table 3 indicates that inclusion of higher proportion of ethical/Islamic securities in the portfolio yield higher portfolio total return.

\section{Conclusion}

In this paper, we proposed a model which is based on Shari'ah compliant framework, stochastic environment, goal programming and chance constrained approach to solve ethical stochastic multiple objectives programming in portfolio selection. The empirical results show that the overall performance of portfolio that included more ethical/Islamic securities outperform those portfolio that included less ethical/Islamic securities. Secondly, the model results show that the acceptable higher probability of loss has a positive effect on portfolio return which is consistent with the study by Masri (2017).

2523-6547 - Copyright: (C) 2017 The Authors. This is an open access article distributed under the terms of the Creative Commons Attribution License, which permits unrestricted use, distribution, and reproduction in any medium, provided the original author and source are credited. 


\section{References}

Aouni, B. (2009). Multi-attribute portfolio selection: New perspectives. Information Systems and Operational Research, 47(1), 1-4.

Aouni, B. (2010). Portfolio selection through the goal programming model: An overview. Journal of Financial Decision Making, 6(2), 3-15.

Ballestero, E., Bravo, M., Pérez-Gladish, B., Arenas-Parra, M., \& Pla-Santamaria, D. (2012). Socially Responsible Investment: A multicriteria approach to portfolio selection combining ethical and financial objectives. European Journal of Operational Research, 216, 487-494.

Ben Abdelaziz, F., \& Abed, M. (2018). Ethics in Investment and Portfolio Selection: A Review. In H. Masri et al. (Eds.), Financial Decision Aid Using Multiple Criteria. Springer.

Ben Abdelaziz, A., Aouni, B., \& Fayedh, R. E. (2007). Multi-Objective Stochastic Programming for Portfolio Selection. European Journal of Operational Research, 177, 1811-1823.

Charnes, A., \& Cooper, W. W. (1959). Chance-Constrained Programming. Management Science, 6(1), 73-79.

Cowton, C. J. (2004). Managing Financial Performance at an Ethical Investment Fund. Accounting, Auditing \& Accountability Journal, 17(2), 249-275.

Dow Jones Official Website (2011). Retrieved from http://www.djindexes.com/

Gassner, M., \& Philipp, W. (2007). Islamic Finance - Islam-gerechte Finanzanlagen und Finanzierungen. Köln: Bank-Verlag Medien GmbH.

Ghoul, W., \& Karam., P. (2007). MRI and SRI Mutual Funds: A Comparison of Christian, Islamic (Morally Responsible Investing), and Socially Responsible Investing (SRI) Mutual Funds. Journal of Investing, 16(2), 96102.

Maghrebi, N., Mirakhor, A., \& Iqbal, Z. (2015). Intermediate Islamic Finance. Singapore: Wiley.

Markowitz, H. (1952). Portfolio Selection. Journal of Finance, 7(1), 77-91.

Masmoudi, M., \& Ben Abdelaziz, F. (2012). A Recourse Goal Programming Approach for the Portfolio Selection Problem. INFOR Journal, 50(3), 134-139.

Masri H. (2017). A Shariah-compliant portfolio selection model. Journal of the Operational Research Society, $1-7$.

Masri, H. (2015). A multiple stochastic goal programming approach for the agent portfolio selection problem. Annals of Operations Research, 1-14.

Morgan Stanley Capital International (MSCI) Official website (2011). Retrieved from http://www.msci.com/

Rahimie, A. (2010). Analysing the Characteristics and Performance of Islamic Funds: A Critical Review of the Malaysian Case (Doctorate dissertation). Durham University, UK.

Securities Commission (SC) of Malaysia (2011). Retrieved from http://www.sc.com.my

Standard and Poor's (S\&P) Official Website (2011). Retrieved from http://www.standardandpoors.com/

Steuer, R., Qi, Y., \& Hirschberger, M. (2005). Multiple objectives in portfolio selection, Journal of Financial Decision Making, 1(1), 11-26.

2523-6547 - Copyright: (C) 2017 The Authors. This is an open access article distributed under the terms of the Creative Commons Attribution License, which permits unrestricted use, distribution, and reproduction in any medium, provided the original author and source are credited. 
Tariq, A. (2004). Managing Financial Risk of Sukuk Structures MSc International Banking (Master dissertation). Loughborough University, UK, Retrieved from http://kantakji.com/

Zopounidis, C., Doumpos, M., \& Zanakis, S. (1999). Stock Evaluation Using a Preference Disaggregation Methodology. Decision Sciences, 30, 313-336. 
Appendix 1: List of 60 securities

\begin{tabular}{|c|c|}
\hline Islamic securities: & Conventional securities: \\
\hline$\overline{\text { Al-Enmaa Real Estate Company }}$ & Bahrain Car Parks \\
\hline Makkah Construction and Development & Mena Holding Group \\
\hline Taiba Holding & Zad Holding \\
\hline Arriyadh Development & Tamdeen Real Estate \\
\hline Ajial Real Estate Entertainment & Shurooq Investment Services Holding \\
\hline Saudi Real Estate & Al-Arabiya Real Estate \\
\hline Union Properties & Al-Massaleh Real Estate \\
\hline Kuwait Real Estate Company & National Securities \\
\hline Mabanee Company & Global Financial Investments Holding \\
\hline Investors Holding Group & A Sharqiya Investment Holding \\
\hline GFH Financial Group & United Development \\
\hline Commercial Real Estate & International Resorts Company \\
\hline Aayan Real Estate Company & Sanam Real Estate Company \\
\hline Aldar Properties & Privatization Holding \\
\hline RAK Properties & Kuwait Real Estate Holding \\
\hline AWJ Holding & Al Dar National Real Estate \\
\hline Dubai Financial Market & Al-Themar International Holding Company \\
\hline Arkan Al Kuwait Real Estate Company & Al Deera Holding \\
\hline Deyaar Development & Dlala Brokerage and Investment Holding \\
\hline Jabal Omar Development & Al-Salam Group Holding \\
\hline Al Argan International Real Estate & Taameer Real Estate Investment \\
\hline Seef Properties & IFA Hotels and Resorts \\
\hline Abyaar Real Estate Development Company & Tejoori Ltd \\
\hline Dar Al Arkan Real Estate Development Company & Emaar The Economic City \\
\hline First Dubai for Real Estate Development & Kingdom Holding \\
\hline Taiba Kuwaiti Holding & Munshaat Real Estate Projects \\
\hline Mazaya Qatar Real Estate Development & Al Safwa Group Holding \\
\hline Al Mudon International Real Estate & Grand Real Estate \\
\hline & Union Real Estate \\
\hline & Kuwait Commercial Market Complex \\
\hline & Industrial \& Financial Investments \\
\hline & Sorouh Real Estate \\
\hline
\end{tabular}

2523-6547 - Copyright: (C) 2017 The Authors. This is an open access article distributed under the terms of the Creative Commons Attribution License, which permits unrestricted use, distribution, and reproduction in any medium, provided the original author and source are credited. 